\title{
Increasing mass loss from Greenland's Mittivakkat Gletscher
}

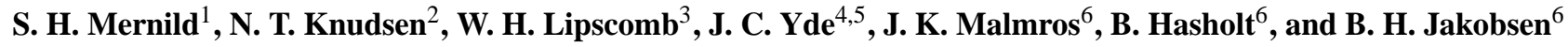 \\ ${ }^{1}$ Climate, Ocean, and Sea Ice Modeling Group, Computational Physics and Methods, Los Alamos National Laboratory, Los \\ Alamos, New Mexico 87545, USA \\ ${ }^{2}$ Department of Geology, Aarhus University, 8000 Aarhus, Denmark \\ ${ }^{3}$ Climate, Ocean, and Sea Ice Modeling Group, Fluid Dynamics and Solid Mechanics, Los Alamos National Laboratory, Los \\ Alamos, New Mexico 87545, USA \\ ${ }^{4}$ Center for Geomicrobiology, Aarhus University, 8000 Aarhus, Denmark \\ ${ }^{5}$ Sogn og Fjordane University College, 6851 Sogndal, Norway \\ ${ }^{6}$ Department of Geography and Geology, University of Copenhagen, 1350 Copenhagen, Denmark
}

Received: 22 January 2011 - Published in The Cryosphere Discuss.: 4 February 2011

Revised: 7 April 2011 - Accepted: 8 April 2011 - Published: 14 April 2011

\begin{abstract}
Warming in the Arctic during the past several decades has caused glaciers to thin and retreat, and recent mass loss from the Greenland Ice Sheet is well documented. Local glaciers peripheral to the ice sheet are also retreating, but few mass-balance observations are available to quantify that retreat and determine the extent to which these glaciers are out of equilibrium with present-day climate. Here, we document record mass loss in 2009/10 for the Mittivakkat Gletscher (henceforth MG), the only local glacier in Greenland for which there exist long-term observations of both the surface mass balance and glacier front fluctuations. We attribute this mass loss primarily to record high mean summer (June-August) temperatures in combination with lowerthan-average winter precipitation. Also, we use the $15-\mathrm{yr}$ mass-balance record to estimate present-day and equilibrium accumulation-area ratios for the MG. We show that the glacier is significantly out of balance and will likely lose at least $70 \%$ of its current area and $80 \%$ of its volume even in the absence of further climate changes. Temperature records from coastal stations in Southeast Greenland suggest that recent MG mass losses are not merely a local phenomenon, but are indicative of glacier changes in the broader region. Massbalance observations for the MG therefore provide unique documentation of the general retreat of Southeast Greenland's local glaciers under ongoing climate warming.
\end{abstract}

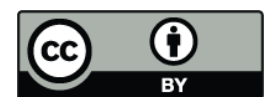

Correspondence to: S. H. Mernild (mernild@lanl.gov)

\section{Introduction}

Greenland has warmed significantly during the past two decades. Summer air temperatures in Greenland's coastal areas increased by an estimated $1.7^{\circ} \mathrm{C}$, on average, from 1991 to 2006 (Comiso, 2006). Mass loss from the Greenland Ice Sheet (GrIS) and from smaller glaciers and ice caps is making a significant and growing contribution to global sea-level rise (Dowdeswell, 2006; Meier et al., 2007; van den Broeke, 2009; Dyurgerov et al., 2009; Mernild et al., 2010). Recent mass-balance estimates for Greenland have focused on the main ice sheet (Hanna et al., 2008; Ettema et al., 2009). In 2010, Greenland experienced record-setting surface melt extent and glacier area loss due to a relatively warm, dry winter followed by an exceptionally warm summer. Mean recorded temperatures were 0.6 to $2.4^{\circ} \mathrm{C}$ above the $1971-2000$ baseline, with the largest anomalies in the west, where melt rates were the highest since systematic observations began in 1990 (Box et al., 2010; Tedesco et al., 2011). Greenland last experienced comparable conditions in 2007, when high summer temperatures led to increased melting (Mote, 2007; Tedesco, 2007; Steffen et al., 2008), surface mass loss, and freshwater runoff (Mernild and Hasholt, 2009). As the climate has warmed, Greenland's outlet glaciers have accelerated and thinned, and the surface mass balance has become more negative. During the past several years the GrIS is estimated to have lost mass at a rate of more than $200 \mathrm{Gt} \mathrm{yr}^{-1}$ (Allison et al., 2009).

Comparable estimates are not available for glaciers and ice caps (GIC) peripheral to the main ice sheet. Although GIC have a relatively small total mass (an estimated $4.4 \mathrm{~cm}$

Published by Copernicus Publications on behalf of the European Geosciences Union. 


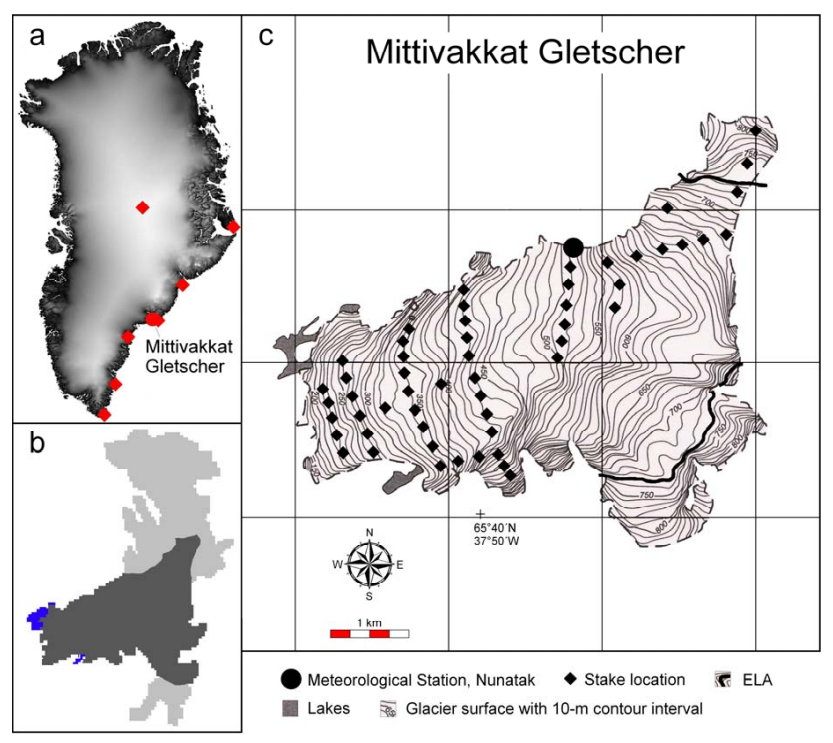

Fig. 1. (a) Location of the Mittivakkat Gletscher (red circle) and coastal meteorological stations (red diamonds) in Southeast Greenland; (b) glacier outline where net balance has been observed (dark gray), along with lobes to the north and south (light gray) that lie in distinct drainage basins; and (c) topographic map (10-m contour interval), with a black circle showing the location of the meteorological station at the nunatak on the glacier, black diamonds showing the stake locations for the glacier observation program (due to a high density of crevasses SE of the glacier, no stakes were located there), and black lines showing the average equilibrium line since 1995.

sea-level equivalent for Greenland and $60 \mathrm{~cm}$ globally Radić and Hock, 2010), they are sensitive to surface-massbalance changes and can equilibrate to climate changes on time scales short compared to ice-sheet response times. The rate of global mean sea-level rise resulting from GIC retreat has been estimated to be $\sim 1 \mathrm{~mm} \mathrm{yr}^{-1}$ (Meier et al., 2007), comparable to that from the Greenland and Antarctic ice sheets combined (Velicogna, 2009). This study provides information about the only local glacier in Greenland (WGMS, 2009) - the Mittivakkat Gletscher in SE Greenland (Fig. 1) for which there exist long-term observations of both the surface mass balance (since 1995) and glacier front fluctuations (since the maximum Little Ice Age (LIA) extension around 1900). We estimate accumulation-area ratios for the MG to quantify the extent to which the glacier is out of balance with present-day climate, and we suggest that recent MG mass losses are not merely a local phenomenon but are indicative of regional changes.

\section{Methods and historical data}

As a result of harsh climate conditions and logistical difficulties, few reliable long-term observations of mass loss and

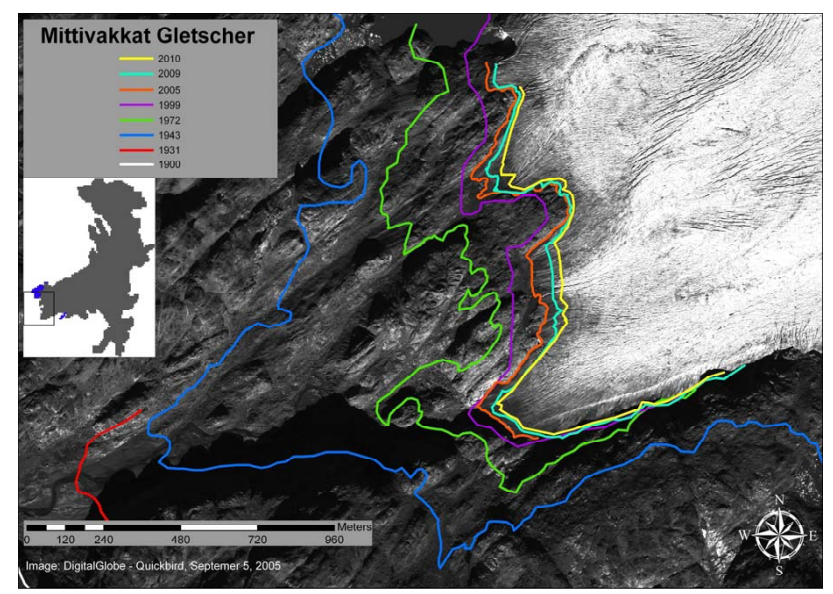

Fig. 2. The location of the Mittivakkat Gletscher margin delineated as thick lines for 1900, 1931, 1943, 1972, 1999, 2005, 2009, and 2010. The 1900 LIA trimline (white line) was estimated from field observations (Hasholt et al., 2008; Humlum and Christiansen, 2008) and is partly shown in the lower left corner of the satellite image. The 1931, 1943, and 1972 margins were estimated from aerial photos, the 1999 margin from Landsat 5, and the 2005 margin from Quickbird. The more recent margins 2009 and 2010 were obtained from topographic surveys (Kern Theodolite observations) and GPS measurements. The Mittivakkat Gletscher outline is shown at left with a black square indicating the photographic area (background photo: DigitalGlobe, Quickbird, 2005).

retreat are available for Greenland's peripheral glaciers. The Mittivakkat Gletscher in Southeast Greenland $\left(17.6 \mathrm{~km}^{2}\right.$; $65^{\circ} 41 \mathrm{~N}, 37^{\circ} 48 \mathrm{~W}$ ) is an exception. This glacier and the surrounding landscape have been photographed at regular intervals since 1931, supplemented more recently by topographic surveys. In 1995 the observing program was expanded with the initiation of continuous and annual surface-mass-balance measurements and an automated glacier climate program. These measurements are supplemented by meteorological data from the coastal town of Tasiilaq, $15 \mathrm{~km}$ to the southeast.

As illustrated by Figs. 2 and 3 and Table 1, the glacier terminus has retreated by about $1600 \mathrm{~m}$ since the maximum LIA extension around 1900 and by $1300 \mathrm{~m}$ since 1931 . Table 1 shows terminus changes for the intervals noted in Fig. 2, indicating average retreat rates ranging from $\sim 6 \mathrm{~m} \mathrm{yr}^{-1}$ (19992005) to $\sim 24 \mathrm{~m} \mathrm{yr}^{-1}$ (1943-1972). The retreat of the MG terminus is influenced by (1) the transition from valley to peak topography as the terminus moves inland from the fjord and the shadow effect from the surrounding mountains (Mernild and Liston, 2010), (2) climate variability, and (3) dynamic processes within the glacier. Therefore, a warming signal from the changing climate may not be seen immediately as a glacier margin retreat. For example, the period from 1931 to 1943 was exceptionally warm, as indicated by mean-annual-air-temperature (MAAT) anomalies in Tasiilaq, but the maximum average retreat rate of $\sim 24 \mathrm{~m} \mathrm{yr}^{-1}$ was observed later, from 1943 to 1972. 

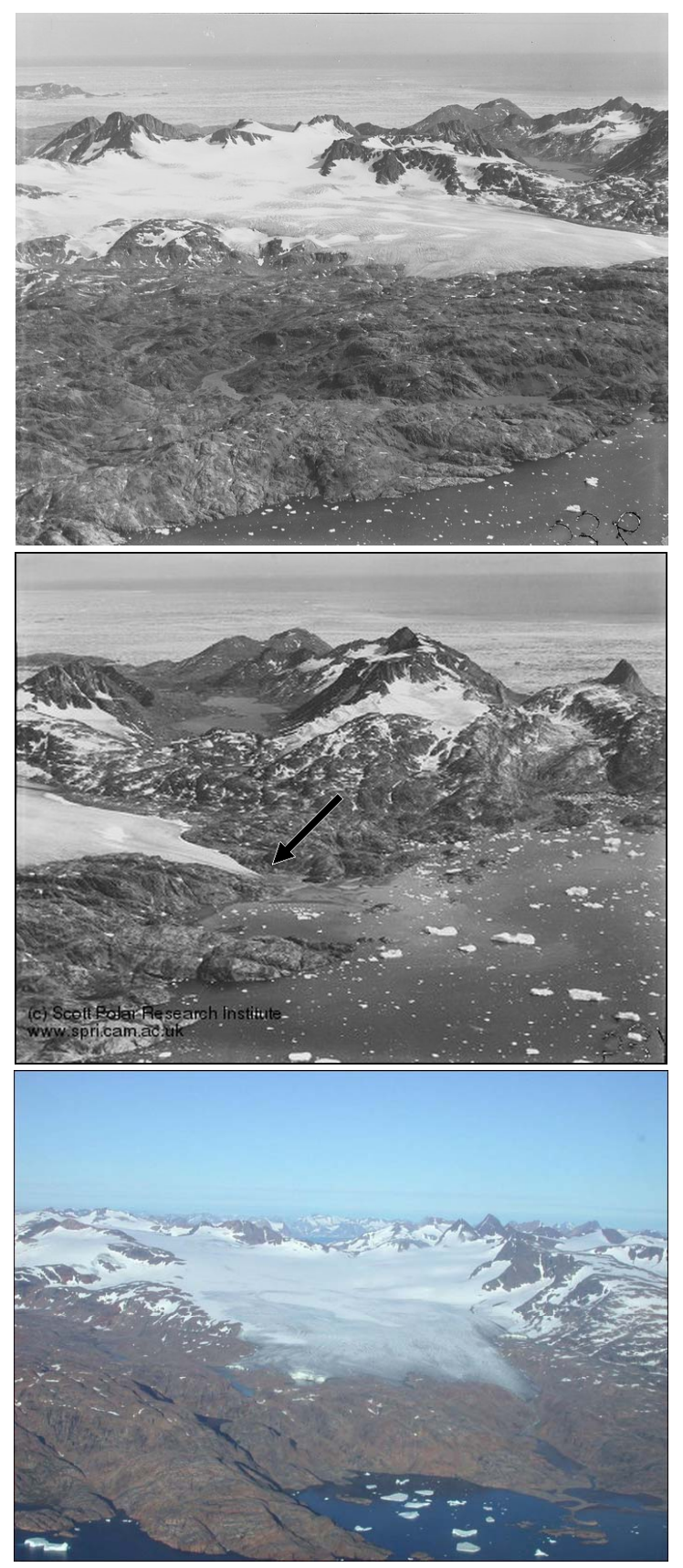

Fig. 3. (above, in black and white) Photographs of the Mittivakkat Gletscher in 1931, when the glacier margin, shown by the arrow, was within $200 \mathrm{~m}$ of the coastline. The photos are taken toward SSE, with Sermilik Fjord in the foreground and the Irminger Sea in the background (licensed with permission of the Scott Polar Research Institute, University of Cambridge, taken on the British Arctic Air Route Expedition, 1930-1931). (below, in color) Photograph of the MG in 2006, when the glacier margin was approximately $1500 \mathrm{~m}$ from the coast. The photo is taken toward ESE (Department of Geography and Geology, University of Copenhagen).
The annual surface mass balance of the MG has been recorded since 1995/96 (Knudsen and Hasholt, 2004, 2008). In 10 out of $15 \mathrm{yr}$, both winter mass balance (accumulation measured at the end of May) and summer mass balance (ablation measured at the end of August) were observed. The stake method - also known as the "direct glaciological method" (Ostrem and Brugman, 1991) - was used to determine annual variations and trends in ice/snow extent and ice volume and to calculate the equilibrium line altitude (ELA) (the ELA is the spatially averaged elevation of the equilibrium line, defined as the set of points on the glacier surface where the net mass balance is zero). Snow accumulation and snow/ice ablation were measured using cross-glacier stake lines at separations of approximately $500 \mathrm{~m}$. The stakes in each line were 200-250 m apart, and measurements were obtained at a total of 45-50 stakes (Fig. 1c). End-of-winter snow density was measured vertically at $25-\mathrm{cm}$ depth intervals in pits at 250, 500, and $750 \mathrm{~m}$ above sea level (a.s.1.). The observed mass balance is considered to be accurate to within $\sim 15 \%$ for the entire glacier, although larger errors may occur locally, particularly in crevassed areas (Knudsen and Hasholt, 2004).

Meteorological conditions at the MG have been recorded since 1995 at an automated weather station operated by the Department of Geography and Geology, University of Copenhagen, located on a small nunatak at $515 \mathrm{~m}$ a.s.l., just below the average ELA. Long-term (1900-2010) climate data representative of the region are available from a synoptic meteorological station at $44 \mathrm{~m}$ a.s.l., operated by the Danish Meteorological Institute and located $15 \mathrm{~km}$ to the southeast of the MG in the outskirts of Tasiilaq.

\section{Results and discussion}

Figure 4 shows the net mass balance of the MG as a function of elevation from 1995/96 to 2009/10, and Fig. 5a shows the average annual net balance for the entire glacier. The glacier mass balance has been negative in 13 out of $15 \mathrm{yr}$. Table 2 gives the ELA in each year, ranging from $390 \mathrm{~m}$ a.s.l. to more than $930 \mathrm{~m}$ a.s.l. with an average of about $730 \mathrm{~m}$ a.s.l. In several years (1998, 2001, 2005, 2007, and 2010), net ablation was recorded at all elevations between the summit (930 $\mathrm{m}$ a.s.1.) and the terminus ( $180 \mathrm{~m}$ a.s.1.).

Data collected during 2009-2010 show that the MG experienced an average surface mass loss of $2.16 \mathrm{~m}$ water equivalent (w.e.), or about $2 \%$ of the total glacier volume, from September 2009 through August 2010. This was the greatest annual mass loss since the expansion of the observing program in 1995, $0.34 \mathrm{~m}$ more than the previous observed record loss in 2005 and significantly above the 15 -yr average loss of $0.87 \pm 0.17 \mathrm{~m} \mathrm{yr}^{-1}$ (Fig. 5a). The 2009/10 loss exceeded (insignificantly) the maximum annual loss of $1.87 \mathrm{~m}$ w.e. (in 1940, during the early-twentieth-century warming) obtained in a model simulation of the MG surface mass balance from 
Table 1. Mittivakkat Gletscher terminus changes and Tasiilaq MAAT anomaly for the intervals noted in Fig. 2.

\begin{tabular}{|c|c|c|c|c|c|c|c|c|c|}
\hline \multicolumn{2}{|l|}{ Interval } & $\begin{array}{r}1900^{*}- \\
1931\end{array}$ & $\begin{array}{r}1931- \\
1943\end{array}$ & $\begin{array}{r}1943- \\
1972\end{array}$ & $\begin{array}{r}1972- \\
1999\end{array}$ & $\begin{array}{r}1999- \\
2005\end{array}$ & $\begin{array}{r}2005- \\
2009\end{array}$ & $\begin{array}{r}2009- \\
2010\end{array}$ & $\begin{array}{r}\text { Average, } \\
1900-2010\end{array}$ \\
\hline \multicolumn{2}{|c|}{$\begin{array}{l}\text { Mittivakkat Gletscher average } \\
\text { terminus changes }\left(\mathrm{m} \mathrm{yr}^{-1}\right)\end{array}$} & -8 & -14 & -24 & -15 & -6 & -10 & -19 & -15 \\
\hline \multirow{3}{*}{$\begin{array}{l}\text { Tasiilaq MAAT } \\
\text { anomaly (five year } \\
\text { running average) }\left({ }^{\circ} \mathrm{C}\right)\end{array}$} & Maximum & 1.07 & 1.35 & 0.81 & 0.26 & 1.27 & 0.85 & - & - \\
\hline & Average & -0.24 & 0.82 & -0.01 & -0.55 & 1.00 & 0.79 & - & - \\
\hline & Minimum & -1.05 & 0.49 & 1.39 & -1.22 & 0.40 & 0.73 & - & - \\
\hline
\end{tabular}

* The LIA trimline and moraine are estimated from field observations (Hasholt et al., 2008; Humlum and Christiansen, 2008). The trimline is the maximum extension since around 1900 .

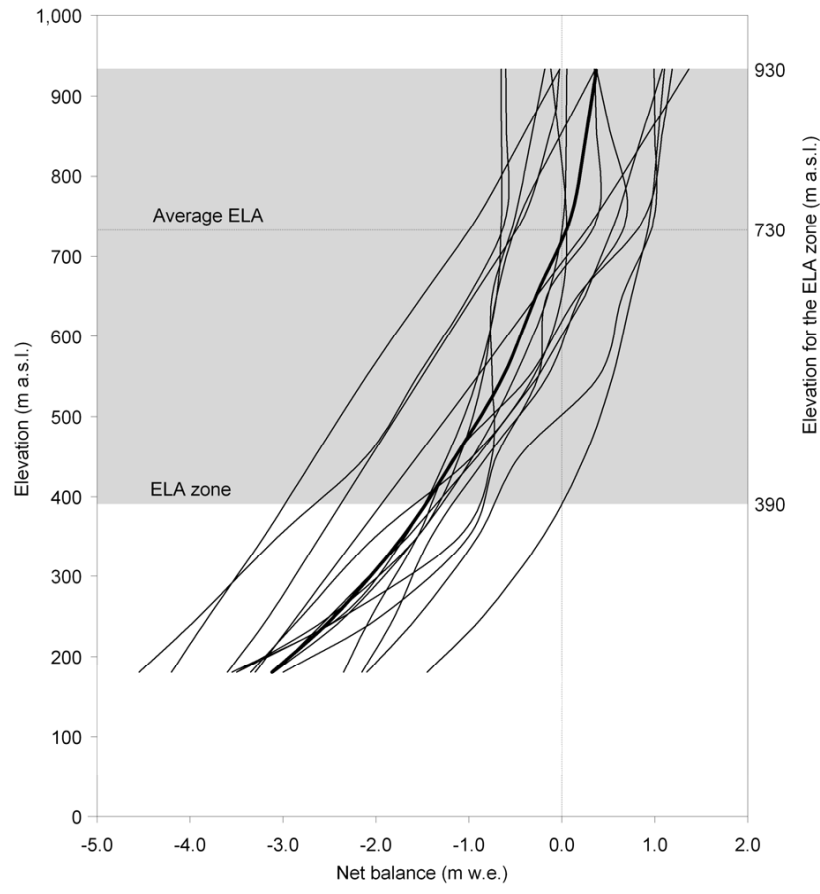

Fig. 4. Variation of the net annual mass balance with altitude for the Mittivakkat Gletscher, 1995-2010. The bold line is the average, and the different years are not labeled individually. The net balance data reported here are updated from Knudsen and Hasholt (2008).

1898 to 1993 (Mernild et al., 2008). At the glacier terminus (below $200 \mathrm{~m}$ a.s.1.) the observed area-averaged 2010 melt rate was $4.2 \mathrm{~m}$, similar to the values of $4.6 \mathrm{~m}$ and $3.6 \mathrm{~m}$ observed in 2005 and 2007, respectively, and almost twice the 15 -yr average of approximately $2.5 \mathrm{~m}$.

Local meteorological data indicate that higher-thanaverage temperatures, along with lower-than-average winter precipitation, were primarily responsible for this record mass loss. During the 2010 summer ablation season (June through August) the mean MG air temperature recorded at $515 \mathrm{~m}$ a.s.l. was $7.5^{\circ} \mathrm{C}$, and the mean temperature at Tasi-
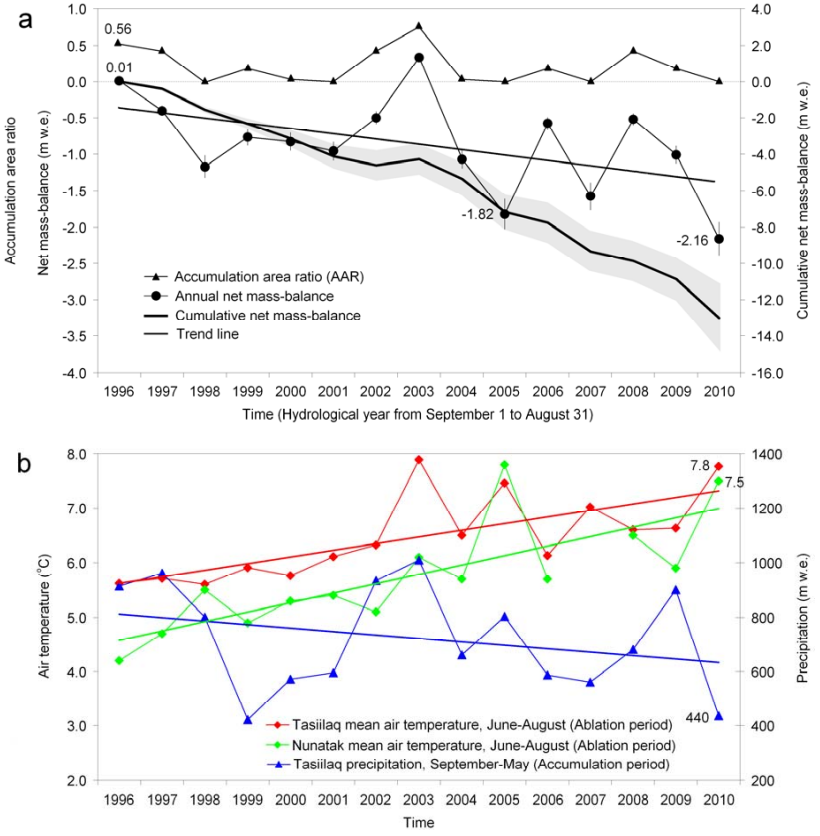

Fig. 5. (a) Observed annual mass balance (with $15 \%$ error bars), cumulative net mass balance (with a gray zone indicating the $15 \%$ error), and accumulation-area ratio for the Mittivakkat Gletscher, 1995-2010. (b) Time series (1995-2010) of observed winter precipitation (September-May) and mean summer air temperature (June-August) from Tasiilaq (44 ma.s.1.) and Station Nunatak (515 $\mathrm{m}$ a.s.1.). The straight lines are linear fits to the data; the two temperature trends are statistically significant.

ilaq was $7.8^{\circ} \mathrm{C}$ (Fig. 5b). These values are $1.8^{\circ} \mathrm{C}$ and $1.4^{\circ} \mathrm{C}$, respectively, above the $1995-2010$ average. During the 2009/10 winter accumulation season (September through May), mean temperatures at the MG and Tasiilaq were $-3.4^{\circ} \mathrm{C}$ and $-2.0^{\circ} \mathrm{C}$, respectively, or $1.3^{\circ} \mathrm{C}$ and $0.5^{\circ} \mathrm{C}$ above average. Uncorrected winter precipitation at Tasiilaq was $\sim 440 \mathrm{~mm}$ w.e., or $\sim 260 \mathrm{~mm}$ w.e. $(\sim 40 \%)$ below the 15 yr average (Fig. 5b). Glacier ice was exposed in late June 2010 (Anders Anker Bjørk, personal communication, March 
Table 2. Annual ELA for Mittivakkat Gletscher, 1995-2010.

\begin{tabular}{lr}
\hline Year & ELA (m a.s.1.) \\
\hline $1995 / 96$ & 500 \\
$1996 / 97$ & 590 \\
$1997 / 98$ & 930 \\
$1998 / 99$ & 740 \\
$1999 / 00$ & 650 \\
$2000 / 01$ & $>930$ \\
$2001 / 02$ & 620 \\
$2002 / 03$ & 390 \\
$2003 / 04$ & 850 \\
$2004 / 05$ & $>930$ \\
$2005 / 06$ & 680 \\
$2006 / 07$ & $>930$ \\
$2007 / 08$ & 600 \\
$2008 / 09$ & 690 \\
$2009 / 10$ & $>930$ \\
Average & $\sim 730$ \\
\hline
\end{tabular}

2011), two to three weeks earlier than average. Mernild et al. (2008) found significant relationships $(p<0.01$, where $p$ is the level of significance) between uncorrected winter precipitation at Tasiilaq and MG winter balance $(n=8$, $\left.r^{2}=0.68\right)$ and between summer temperature at Tasiilaq and MG summer balance $\left(n=8, r^{2}=0.55\right)$. High summer temperatures favor increased surface ablation (evaporation, sublimation, and melt). Low winter snowfall leads to earlier exposure of glacier ice and of the previous year's summer snow surface; these surfaces have a lower albedo than fresh snow (Oke 1987), promoting greater solar absorption and increased melting. Although high winter temperatures could contribute to an early start of the melt season by decreasing the "cold content" of the snow (Bøggild et al., 2005), the correlation between winter temperatures and annual mass balance has not been found to be significant (Mernild et al., 2008). Similar weather conditions were observed in 2009/10 throughout Greenland, more pronounced in the west and less so in the northeast (Box et al., 2010; Tedesco et al., 2011).

The general trend for the MG since 1995 has been toward higher summer temperatures, less winter precipitation, and a more negative glacier mass balance (Fig. 5). Summer temperatures have increased significantly $(p<0.01)$ at both meteorological stations, by $1.7^{\circ} \mathrm{C}$ at the $\mathrm{MG}$ and by $1.8^{\circ} \mathrm{C}$ at Tasiilaq. Winter precipitation has declined by $\sim 230 \mathrm{~mm}$ w.e., although this change is within the variability of the 15 yr record (Fig. 5b). The two years with a slightly positive mass balance, 1995/96 (0.01 m w.e.) and 2002/2003 (0.34 m w.e.), were associated with unusually high winter precipitation (around $1000 \mathrm{~mm}$ w.e.) and mean summer temperatures of 4.2 and $6.1^{\circ} \mathrm{C}$ (Station Nunatak) and 5.6 and $7.9^{\circ} \mathrm{C}$ (Station Tasiilaq), respectively. Figure 5 a shows the cumulative net mass balance for the MG since 1995/96. The total mass
Table 3. Area and accumulation-area ratios. The left column lists Mittivakkat Gletscher elevation bands at 100-m intervals; the middle column gives the glacier area located within each band; and the right column gives the estimated AAR when the ELA falls within the given band.

\begin{tabular}{rrr}
\hline MG elevation bands (m a.s.1.) & Area $\left(\mathrm{km}^{2}\right)$ & AAR \\
\hline$>930$ & - & 0.00 \\
$800-930$ & 0.77 & 0.04 \\
$700-799$ & 2.65 & 0.19 \\
$600-699$ & 3.99 & 0.42 \\
$500-599$ & 2.70 & 0.56 \\
$400-499$ & 3.16 & 0.75 \\
$300-399$ & 2.35 & 0.89 \\
$200-299$ & 1.44 & 0.97 \\
$<200$ & 0.54 & 1.00 \\
Total & 17.6 & - \\
\hline
\end{tabular}

loss is estimated at $13.0 \pm 1.9 \mathrm{~m}$ w.e., or $11 \%$ of the total ice volume determined in 1994 (Knudsen and Hasholt, 1999). Since 1995 the glacier terminus has retreated by about $110 \mathrm{~m}$, as illustrated by the front observations (Fig. 2 and Table 1).

The recent trends for the MG region are consistent with long-term climate trends since 1900 for Tasiilaq, where the temperature anomaly is almost in anti-phase with the precipitation anomaly (Mernild et al., 2011). During periods with a decreasing trend in precipitation (e.g., from 1900 until the 1930s and 1970 to the present), the temperature trend was increasing, and visa versa. Although there have been periods of higher-than-average precipitation and lower-than-average temperature (Mernild et al., 2011), the MG terminus has retreated continuously since the maximum LIA extension.

The long-term record of surface temperature in Tasiilaq is reproduced in Fig. 6, together with meteorological observations from Southeast Greenland's coastal stations (ranging in elevation from 13 to $88 \mathrm{~m}$ a.s.l.), and from the Summit station at the top of the Greenland Ice Sheet (3208 m a.s.1.). MAAT anomalies at Station Tasiilaq are significantly correlated with MAAT anomalies at other coastal stations $\left(r^{2}\right.$ values of $0.61-$ $0.91, p<0.01)$, and at Summit $\left(r^{2}=0.42, p<0.10\right)$. These data suggest that recent MG mass losses, which have been driven largely by higher surface temperatures, are representative of the broader region, which includes many hundreds of local glaciers. Observations of glaciers in the Mittivakkat region, including Sermilik Fjord and Ammassalik Island, show terminus retreats comparable to that of MG. These glaciers are almost similar to the MG in size and elevation range.

The accumulation-area ratio (AAR: the ratio of the accumulation area to the area of the entire glacier) has been estimated for the MG each year from 1995/96 to 2009/10 (Fig. 5a), a period long enough to filter out high-frequency interannual variability but significantly shorter than the time scale of adjustment to equilibrium. As shown in Table 3, 


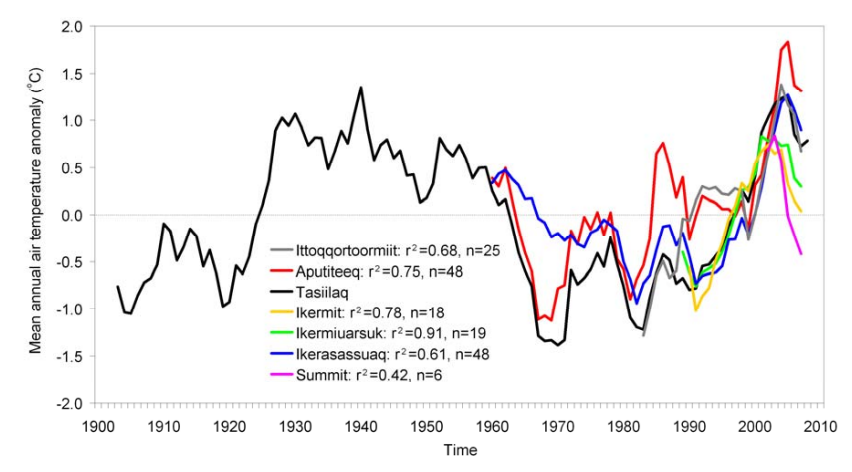

Fig. 6. Long-term time series of observed MAAT anomaly (five year running average) from Tasiilaq and other meteorological stations in Southeast Greenland. The $r^{2}$ values indicate the correlation between the Tasiilaq anomaly and anomalies from other stations shown in Fig. 1a (Ittoqqortoormiit is farthest north, and Ikerasassuaq is farthest south).

the glacier is partitioned into 100-m elevation bands, and the AAR for a given year is determined based on the glacier area above and below the ELA. The average AAR is 0.15 and can be determined as follows. A linear regression between the AAR and the surface mass balance $\left(r^{2}=0.89, p<0.01\right)$ gives the relation $\mathrm{AAR}=m \cdot b+\mathrm{AAR}_{0}$, where $b$ is the net mass balance $\left(\mathrm{m} \mathrm{yr}^{-1}\right), m=0.49 \mathrm{~m}^{-1} \mathrm{yr}$ is the slope, and $\mathrm{AAR}_{0}=0.61$ is the AAR when $b=0$. Zero values of AAR are excluded from the regression, since AAR and mass balance are not linearly related when net ablation occurs everywhere on the glacier. Based on this regression, the average AAR is defined as the predicted AAR during a year when the mass balance is equal to its 15 -yr mean value of $-0.87 \mathrm{~m} \mathrm{yr}^{-1}$. The resulting average AAR of 0.15 is slightly lower than the 15 -yr arithmetic mean AAR of 0.22 , which includes several years of strongly negative mass balance and zero AAR.

Glaciers and ice caps (GIC) in equilibrium with local climate typically have an AAR of 0.5-0.6, with a global average of $0.579 \pm 0.009$ (Dyurgerov et al., 2009). Expected changes in glacier area and volume can be derived from $\alpha_{r}=\mathrm{AAR} / \mathrm{AAR}_{0}$, the ratio of the current AAR to its equilibrium value. (Specifically, $p_{s}=\alpha_{r}-1$ and $p_{v}=\alpha_{r}^{\gamma}-1$, where $p_{s}$ is the expected fractional area change, $p_{v}$ is the fractional volume change, and $\gamma=1.36$ is an empirical constant $-\mathrm{Bahr}$ et al., 2009). As stated above, the MG has an $\mathrm{AAR}_{0}$ of approximately 0.61 , close to the global average. The resulting $\alpha_{r}=0.25 \pm 0.08$ implies that the MG will lose about $75 \pm 8 \%$ of its present area and $85 \pm 7 \%$ of its volume (a volume loss of $\sim 1.5 \pm 0.1 \mathrm{~km}^{3}$ ) if current climate conditions persist.

\section{Summary and conclusion}

Local glacier observations in Greenland are rare, and the MG is the only glacier in Greenland for which long-term observations of both the surface mass balance and glacier front fluctuations exist. Since 1995, the general trend for the MG has been toward higher temperatures, less snowfall, and a more negative glacier mass balance, with record mass loss in 2009/10. In 13 of the last $15 \mathrm{yr}$, the MG had a negative surface mass balance. The two years with a slightly positive balance were associated with unusually high winter precipitation. The MG is significantly out of balance; an analysis of accumulation-area ratios suggests that the glacier will likely lose at least $70 \%$ of its current area and $80 \%$ of its volume even in the absence of further climate changes.

Bahr et al. (2009) carried out a global analysis of glacier AARs to obtain lower bounds for global sea-level rise associated with expected GIC mass loss. They computed an average AAR $=0.44$ from 1997-2006 for a global sample of 86 glaciers and ice caps, and they estimated that GIC must lose at least $27 \%$ of their volume (the equivalent of an 18 $\mathrm{cm}$ rise in global average sea level) in order to reestablish equilibrium under present-day conditions. None of the 86 glaciers in their dataset is located in Greenland. Given that the average AAR for the MG is well below the global average and is likely to be typical of many of Greenland's peripheral glaciers, observations of the mass balance of Mittivakkat Gletscher are relevant to more informed estimates of future glacier retreat and sea-level rise.

During the last century, mean temperatures in Tasiilaq have been characterized by early-twentieth-century warming (ETCW) from 1900 until the 1930s and late-twentiethcentury warming (LTCW) from 1970 to the present, interrupted by several decades of mid-century cooling (Fig. 6). Higher temperatures have generally been associated with lower precipitation, and vice versa (Mernild et al., 2011). Both the ETCW and the mid-century cooling appear to be connected to internal variability in the North Atlantic Ocean (Brönnimann, 2009), whereas it is generally accepted that the LTCW is a regional amplification of global warming driven mainly by increased fossil fuel burning (IPCC, 2007; Chylek et al., 2010). To the extent that the recent warming is anthropogenic in origin, temperatures in the Mittivakkat region are likely to continue to increase, leading to larger area and volume losses than are projected based on the current average AAR, and possibly to the complete melting of the MG and other local glaciers of Southeast Greenland.

Acknowledgements. We thank Mauri Pelto, Xavier Fettweis, and two anonymous reviewers for their insightful critiques. This work was supported by grants from the Climate Change Prediction Program and Scientific Discovery for Advanced Computing (SciDAC) program within the US Department of Energy's Office of Science, by a Los Alamos National Laboratory (LANL) Director's Fellowship, and by a fellowship from the LANL Institute for Geophysics and Planetary Physics. LANL is operated under the 
auspices of the National Nuclear Security Administration of the US Department of Energy under Contract No. DE-AC52-06NA25396. Field work was supported by grants from the Danish Research Council under the frame program on climate and Arctic landscape processes carried out at the Institute of Geography and Geology, Copenhagen University, and by the Department of Earth Sciences, University of Aarhus. We thank David Bahr, Matthew Hecht, and Wilbert Weijer for helpful comments. Thanks are given to the Danish Meteorological Institute for providing WMO synoptic meteorological data from the East Greenland stations.

Edited by: E. Hanna

\section{References}

Allison, I., Bindoff, N. L., Bindschadler, R. A., Cox, P. M., de Noblet, N., England, M. H., Francis, J. E., Gruber, N., Haywood, A. M., Karoly, D. J., Kaser, G., Le Qu'er'e, C., Lenton, T. M., Mann, M. E., McNeil, B. I., Pitman, A. J., Rahmstorf, S., Rignot, E., Schellnhuber, H. J., Schneider, S. H., Sherwood, S. C., Somerville, R. C. J., Steffen, K., Steig, E. J., Visbeck, M., and Weaver, A. J.: The Copenhagen Diagnosis: Updating the World on the Latest Climate Science. The University of New South Wales Climate Change Research Centre (CCRC), Sydney, Australia, 60 pp., 2009.

Bahr, D. B., Dyurgerov, M., and Meier, M. F.: Sea-level rise from glaciers and ice caps: A lower bound, Geophys. Res. Lett., 36, L03501, doi:10.1029/2008GL036309, 2009.

Box, J. E., Cappelen, J., Decker, D., Fettweis, X., Mote, T., Tedesco, M., and Van de Wal, R. S. W.: Greenland [in Arctic Report Card 2010], http://www.arctic.noaa.gov/reportcard, 2010.

Brönnimann, S.: Early twentieth-century warming, Nat. Geosci., 2, 735-736, 2009.

Bøggild, C. E., Forsberg, R., and Reeh, N. Melt: Water in a transect across the Greenland ice sheet, Ann. Glaciol., 40, 169-173, 2005.

Chylek, P., Folland, C., Lesins, G., and Dubey, M.: Twenties century bipolar seesaw of the Arctic and Antarctic surface air temperature, Geophys. Res. Lett., 37, L08703, doi:10.1029/2010GL042793, 2010.

Comiso, J.: Arctic warming signals from satellite observations, Weather, 61(3), 70-76, 2006.

Dowdeswell, J. A.: A changing Greenland Ice Sheet and global sealevel rise, Science, 311, 963-964, 2006.

Dyurgerov, M., Meier, M. F., and Bahr, D. B.: A new index of glacier area change; a tool for glacier monitoring, J. Glaciology, 55(192), 710-716, 2009.

Ettema, J., van den Broeke, M., van Meijgaard, E., van de Berg, M. J., Bamber, J. L., Box, J. E., and Bales, R. C.: Higher surface mass balance of the Greenland Ice Sheet revealed by high resolution climate modeling, Geophys. Res. Lett., 36, L12501, doi:10.1029/2009GL038110, 2009.

Hanna, E., Huybrechts, P., Steffen, K., Cappelen, J., Huff, R., Shuman, C., Irvine-Fynn, T., Wise, S., and Griffiths, M.: Increased runoff from melt from the Greenland Ice Sheet: a response to global warming, J. Climate, 21(2), 331-341, 2008.

Hasholt, B., Krüger, J., and Skjernaa, L.: Landscape and sediment processes in a proglacial valley, the Mittivakkat Glacier area, Southeast Greenland, Geografisk Tidsskrift, 108(1), 97110, 2008.

Humlum, O. and Christiansen, H. H.: Geomorphology of the Ammassalik Island, SE Greenland, Geografisk Tidsskrift, 108(1), 520, 2008.

IPCC: Climate Change. The Physical Science Basis. Contributing of Working Group I to the Fourth Assessment Report of the Intergovernmental Panel on Climate Change, edited by: Solomon, S., Qin, D., Manning, M., Chen, Z., Marquis, M., Averyt, K. B., Tignor, M., and Miller, H. L., Cambridge University Press, Cambridge, United Kingdom and New York, NY, USA, 996, 2007.

Knudsen, N. T. and Hasholt, B.: Radio-echo Sounding at the Mittivakkat Gletscher, Southeast Greenland, Arctic, Antarctic, and Alpine Research, 31(3), 321-328, 1999.

Knudsen, N. T. and Hasholt, B.: Mass balance observations at Mittivakkat Glacier, southeast Greenland 1995-2002, Nord. Hydrol., 35, 381-390, 2004.

Knudsen, N. T. and Hasholt, B.: Mass balance observations at Mittivakkat Glacier, Ammassalik Island, Southeast Greenland 19952006, Geografisk Tidsskrift, 108(1), 111-120, 2008.

Meier, M. F., Dyurgerov, M. B., Rick, U. K., O’Neel, S., Pfeffer, W. T., Anderson, R. S., Anderson, S. P., and Glazovsky, A. F.: Glaciers dominate eustatic sea-level rise in the 21st century, Science, 317, 1064-1067. doi:10.1126/science.1143906, 2007.

Mernild, S. H. and Hasholt, B.: Observed runoff, jökulhlaups, and suspended sediment load from the Greenland Ice Sheet at Kangerlussuaq, West Greenland, for 2007 and 2008, J. Glaciol., 55(193), 855-858, 2009.

Mernild, S. H. and Liston, G. E.: The influence of air temperature inversion on snow melt and glacier surface mass-balance simulations, SW Ammassalik Island, SE Greenland, J. Appl. Meteorol. Clim., 49(1), 47-67, 2010.

Mernild, S. H., Kane, D. L., Hansen, B. U., Jakobsen, B. H., Hasholt, B., and Knudsen, N. T.: Climate, glacier mass balance, and runoff (1993-2005) for the Mittivakkat Glacier catchment, Ammassalik Island, SE Greenland, and in a long term perspective (1898-1993), Hydrol. Res., 39(4), 239-256, 2008.

Mernild, S. H., Liston, G. E., Hiemstra, C. A., and Christensen, J. H.: Greenland Ice Sheet surface mass-balance modeling in a 131-year perspective 1950-2080, J. Hydrometeorol., 11(1), 325,2010

Mernild, S. H., Seidenkrantz, M.-S., Chylek, P., Liston, G. E., and Hasholt, B.: Climate-driven fluctuations in freshwater to Sermilik Fjord, East Greenland, during the last 4000 years, in press, The Holocene, 2011.

Mote, T. L.: Greenland surface melt trends 1973-2007. Evidence of a large increase in 2007, Geophys. Res. Lett., 34, L22507, doi:10.1029/2007GL031976, 2007.

Oke, T. R.: Boundary Layer Climates. Second Edition, Routledge, 423 pp., 1987.

Ostrem, G. and Brugman, M.: Glacier mass balance measurements. A manual for field and office work, NRHI Science Report, No 4. 224 pp., 1991.

Radić, V. and Hock, R.: Regional and global volumes of glaciers derived from statistical upscaling of glacier inventory data, J. Geophys. Res., 115, F01010, doi:10.1029/2009JF001373, 2010.

Steffen, K., Clark, P. U., Cogley, J. G., Holland, D., Marshall, S., Rignot, E., and Thomas, R.: Rapid changes in glacier and ice sheet and their impacts on sea level, in: Abrupt Climate Change, 
a Report by the US Climate Change Science Program and the Subcommittee on Global Change Research, US Geological Survey, Reston, VA, 60-142, 2008.

Tedesco, M.: A new record in 2007 for melting in Greenland, Eos Trans. AGU, 88(39), 383, 2007.

Tedesco, M., Fettweis, X., van den Broeke, M. R., van de Wal, R. S. W., Smeets, C. J. P. P., van de Berg, W. J., Serreze, M. C., and Box, J. E.: The role of albedo and accumulation in the 2010 melting record in Greenland, Environ. Res. Lett., 6, 014005, 1-6, 2011.

van den Broeke, M., Bamber, J., Ettema, J., Rignot, E., Schrama, E., van de Berg, W. J., van Meijgaard, E., Velicogna, I., and Wouters, B.: Partitioning recent Greenland mass loss, Science, 326, 984986, 2009.
Velicogna, I.: Increasing rates of ice mass loss from the Greenland and Antarctic ice sheets revealed by GRACE, Geophys. Res. Lett., 36, L19503, doi:10.1029/2009GL040222, 2009.

WGMS: Glacier Mass Balance Bulletin. Bulletin No. 10 (2006-2007), edited by: Haeberli, W., Gartner-Roer, I., Hoelzle, M., Paul, F., and Zemp, M., ICSU(WDS)/ IUGG(IACS)/UNEP/UNESCO/WMO, World Glacier Monitoring Service, Zurich, 96 pp., 2009. 